\title{
Mature T-Cell and NK-Cell Non-Hodgkin Lymphoma
}

National Cancer Institute

\section{Source}

National Cancer Institute. Mature T-Cell and NK-Cell Non-Hodgkin Lymphoma. NCI

Thesaurus. Code C3468.

This type of lymphoma is not frequently seen in the western hemisphere. Clinically, with the exception of anaplastic large cell lymphoma, mature T- and NK-cell lymphomas are among the most aggressive of all hematopoietic neoplasms. Representative disease entities include mycosis fungoides, angioimmunoblastic T-cell lymphoma, hepatosplenic T-cell lymphoma, and anaplastic large cell lymphoma. 